\title{
Foreign Language Deadly Boulevard: The Tentative Hypothesis of Novel Corona Virus Policy Manifestation to the English as a Foreign Language \\ Thobias Sarbunan \\ IAKN Ambon \\ thobialex@yahoo.com \\ $8 / 7 / 2020$
}

\begin{abstract}
This article is the purpose to argue the dramatic and crisis situation which affected by corona virus in widespread, especially English as a foreign language which standing as foreign language pioneer that can be dead and or lost when that virus have mutual influence. The topics that discussed were the general issues such as the impact of pandemic to social, politic, policymaker, education, and also English foreign language that spoke and learned by million people globally. In fact, all of those issues have been interrelated to support mutual development of human being wealthiest. So forth, researcher believes that by the several of crisis will impact all of the sectoral to the deep of human disaster even in short, long, and generation by generation. So that through this review, we can reflected, analyzed, and developed the suitable problem solving in used of English as a foreign language as practical foreign language and sustainable implementation of foreign language inquiry in the mid of crisis.
\end{abstract}

Keywords: English Foreign Language; Deadly Boulevard; Third Circle; the Tentative Hypothesis; Novel Corona Virus Policy

\section{Introduction}

The chaos was developing through the pandemic of coronavirus which started from endemic scenario to pandemic as the manifestation of local virus that transformed into the global panic and suffers. Multi-task was deployed to solve the pandemic but in fact, it is played such a shadow which all of the effort to solve like a clutch in the desperate zone. Included education is the one of impact factor for such flu disease, while in English as a foreign language in gradual level was disputed to the human development of language skill in equal and also structural. By that means, the uses of English as a foreign language can be extinct when social mobile has authoritarian and even banded in a massive system.

In the line of the narration beforehand, ("English in Language Policy and Management," 2012, p. 5) stated that English functions somewhat differently in these various societies but the underlying trend is similar: the number of users of English is expanding and English is intruding into more domains more intensively than hitherto, particularly those associated with education, media, advertising and business, and youth culture. Concerns are, therefore, bound to arise regarding the sociolinguistic, socio-economic and cultural effects. And the ubiquity of English also means that it has become 'a factor that needs to be taken into account in its language policy by any nation-state. In other words, when one of the foreign language is take account to the nation policy and has the scope to globe issue, it is should be analyzed and developed in sustainable purposes.

Standard explanations of the emergence of global English emphasize the dual role of the British colonial empire and the economic, military and political dominance of the United States in the second half of the twentieth century as creating the appropriate historical conditions ("English in Language Policy and Management," 2012, p. 5b). And this has tended to give greater influence to supranational (or intergovernmental) organizations such as the (EU, ASEAN, 
NAFTA, the G20) grouping. But even in the far smaller world of academia, there are internationalizing forces: an example would be the (EU) initiated Bologna process, which aims, among other things, to increase student/staff mobility across Europe. In short English language influence the factor of formal, non-formal, and also informal followed by the positive trend.

How these developments relate to the spread of English is relatively straightforward. In the political sphere, again dominated by the United States, many international organizations find English a convenient choice of working language. The dominant presence of English in these domains enhances the labor market value of English skills, and this, in combination with the cultural attractions, helps explain why so many seek competence in the language ("English in Language Policy and Management," 2012, p. 5c). It would seem unrealistic, however, to suppose that millions of Chinese learners are learning English guided by as many as secondary school teachers in response to external pressures exerted by imperialist powers.

The socioeconomic factors those are behind the spread of English are now indigenous in most countries of the world and part and parcel of indigenous daily life and social stratification.

On the contra sides a more important point, however, is that promotion does not entail uptake, as the Soviet Union's limited success in implanting Russian in the former Eastern Bloc countries suggests. Absence of ideological resistance can, of course, that is, processes by which the mass of the population, their consciousness saturated with dominant taken-for-granted discourses, consent to, and thus become complicit with, their own domination and exploitation ("English in Language Policy and Management," 2012, p. 5d). In Malaysia, for example, the leadership justified the decision to reintroduce English as a medium of science and math's instruction in secondary schools (2003) by claiming that English was necessary for Malaysia to remain competitive at an international level and 'to prevent the efficiency and capability of our people from being lower than those in other countries'. The factors determining Q-value (prevalence and centrality) are not very dissimilar to those identified as making languages more or less attractive to acquirers - communicative range (the number of persons one can communicate with in the language) and functional potential (what one can do with the language).

Figure 1:

The Underlined Element of English Widespread

Together, these three elements provide a rather neat explanation of the spread of English.

Hypercollectivity helps explains how spread, once initiated, has a self-accelerating propensity. Q-

value, in this case the high Q-value of English, helps explain what makes English attractive to

would-be acquirers, and the position of English in the global language system helps explain why

English has a high Q-value. The framework allows for agency at the micro-level of individual

decisions and shows how these, when aggregated, can produce outcomes that are unforeseen,

perhaps even undesirable, for these same individuals. 
Figure 2:

The Practical Element of English Widespread

It does, however, have limitations, of which we can mention three. First, while usefully

highlighting the role of individual preference, it tends to overlook the decision-making

interventions of higher level actors - governments, ministries of education and transnational corporations - such as the car-manufacturing giant Nissan-Renault, which decided to make English its working language despite a mainly Japanese and French workforce. Second, the framework under-rates the variability of a language's Q-value, or alternatively its 'market value' (Bourdieu 1991), between different social sectors of a single country. Finally, it seems better suited to explaining the spread of lingua francas, like English, that are adopted mainly for practical, instrumental advantages than to explaining the condition of national languages where identity considerations presumably weigh more heavily.

At the same time, however, individual choices, while not determined, are constrained by an existing socio-economic environment constructed by British colonialism, twentieth-century United State dominance and contemporary forces of globalization. From the language policy perspective, this diffuse agency means, that there is little language policy on its own can do to halt a spreading lingua franca ("English in Language Policy and Management," 2012, p. 5e).

Figure 3:

The Three Principle Criticisms to Global English

A survey of the literature critiquing the effects of global English suggests three principal criticisms:

(a) The spread of English is a threat to global linguistic diversity. It disrupts linguistic ecologies, directly endangering some languages and marginalizing others - principally by dislodging them from important public domains such as higher education and business (see e.g. Phillipson 1992, 2003; Phillipson and Skutnabb-Kangas 1996, 1997, 1999; Mulhausler 1996).

\footnotetext{
(b) English contributes to, and consolidates, socio-economic inequalities within and between countries, leading to inequity. Its spread is implicated in manifest and growing global inequality (see e.g. Pennycook 1995, 2000; Tollefson 1991, 2002; Ricento 2000; Phillipson 2000).

(c) English is implicated in processes of cultural homogenization. Specifically, it is a vector of cultural 'Americanization' (see e.g. Phillipson and Skutnabb-Kangas 1996, 1997, 1999;

Pennycook 1995)
}

This study is focused on how is the situation of global crisis that omitted through novel corona virus (19) and implicated from global policy to systematically conquer the entire sector which education in term of minor point is English as foreign languages develop and also how is the corona virus can be a trigger to the English as a foreign language is dead or lost. Then what is the pathway of English foreign language development when the global crisis will have been embodied all of us, as the perspective of the user and foreign language speaker.

\section{The General Reflection of Global Crisis to Education}

The narrative story of covid (19) was declined global society for nowadays and born as a nightmare to all of us. In the current time, researchers globally have determined that the pandemic will end in one of the following scenarios: 
Immunization (via vaccine), which can potentially take [12 to 18] months (preferred strategy); Herd immunity, if a large portion of the world population contracts the virus (undesirable); Until the vaccine is developed, the world will go through multiple cycles of staggered lockdowns, ranging from [2 to 6] months (Jhingan et al., 2020).

Figure 4:

The Potential Exit Scenario

Potential exit scenarios ${ }^{\star}$

\begin{tabular}{|l|c|c|c|}
\hline \multicolumn{1}{|c|}{ Scenario } & Base or realistic & Optimistic & Pessimistic \\
\hline Countrywide lockdowns & End by summer & End by summer & End in summer, restart in winter \\
\hline Social distancing & 6-12 months & Phased out in summer & $\mathbf{1 2}$ months \\
\hline Global travel & Restricted (essential only) & Close to normal & Restricted (essential only) \\
\hline Work from home & Continuous, where possible & Close to normal & Continuous, where possible \\
\hline Recurrence & Milder winter outbreak & Less likely recurrence & Severe winter outbreak \\
\hline
\end{tabular}

In line, the impact to education in general from the side of students can be determined such as Students who were about the start their education in the coming academic year are stuck in a limbo even after receiving a confirmation letter from their dream universities as there is high uncertainty regarding the onset of classes in August. According to a (QS) survey measuring the impact of coronavirus on higher education, $(\sim 45 \%)$ of prospective international students surveyed have stated the intention to defer their admission until next year, and $(\sim 10 \%)$ have suggested that they no longer intend to study overseas. While from university level, the current batch of students, universities across the world have shifted to online classes, most uncertainty has been around the next intake of students (Jhingan et al., 2020b).

Figure 5:

The Inbound Internationally Mobile Students; Select Countries at 2017

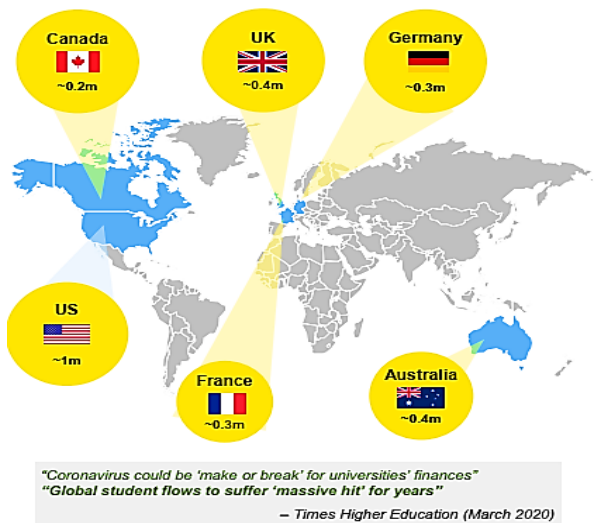


Figure 6:

Disruptions Effect by Novel Corona Virus

All stakeholders - students and parents, providers and investors - in the education sector are facing disruptions

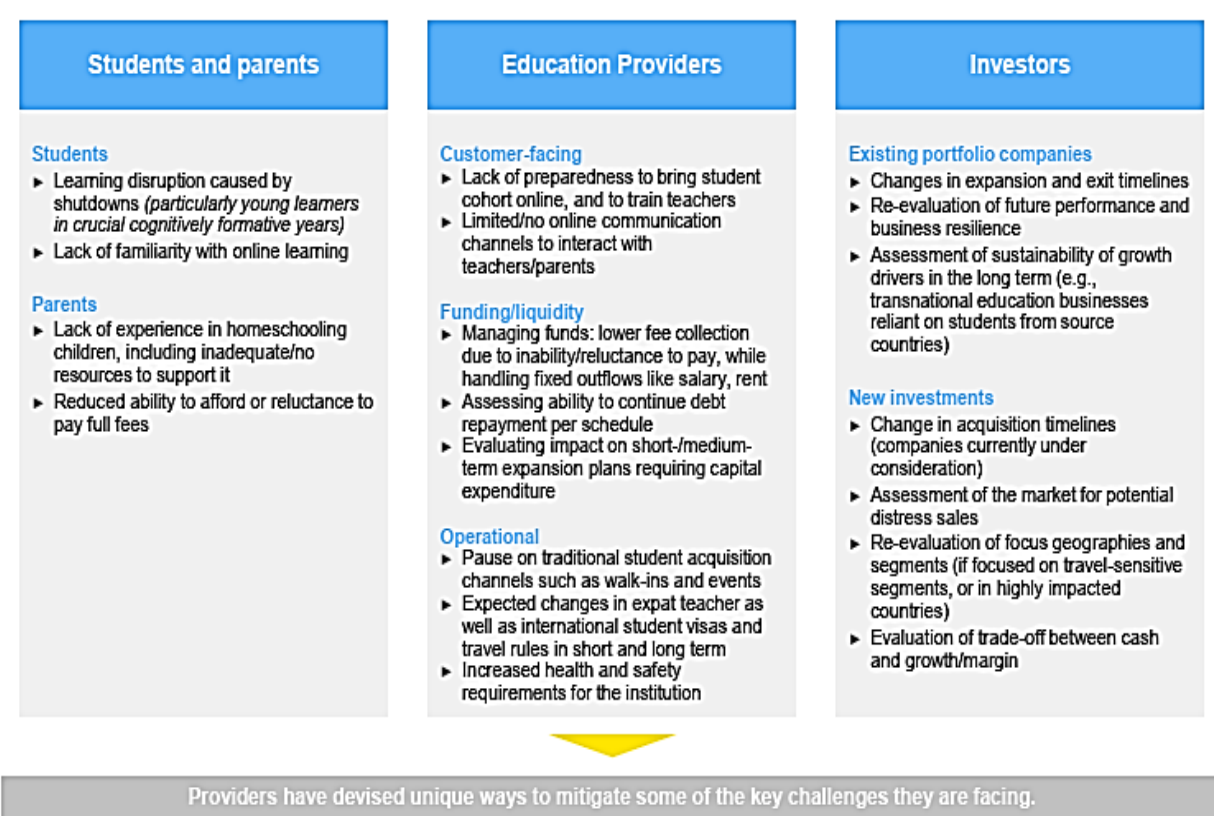

Figure 7:

Conventional to Online Course

\begin{tabular}{|c|c|}
\hline 1 switch to live classes & $\begin{array}{l}\text { Free provision of } \\
\text { technology tools }\end{array}$ \\
\hline $\begin{array}{l}\text { - Large education companies } \\
\text { have switched offline } \\
\text { courses to online and } \\
\text { provided free access to } \\
\text { students in response to the } \\
\text { coviD-19 pandemic. } \\
\text { - Most providers have } \\
\text { switched to live teaching } \\
\text { as creating self-paced } \\
\text { courses is time intensive. }\end{array}$ & $\begin{array}{l}\text { - Online providers have made } \\
\text { both their courses and } \\
\text { technology tools free for } \\
\text { universities and schools to } \\
\text { utilize. } \\
\text { - For example, an online } \\
\text { tutoring company provided } \\
\text { live broadcast tools and } \\
\text { conducted free online } \\
\text { training for teachers to } \\
\text { facilitate the transition to } \\
\text { online. }\end{array}$ \\
\hline
\end{tabular}

\begin{tabular}{|l|l|}
\hline Partinerships & $\begin{array}{c}\text { Student and parent } \\
\text { engagement }\end{array}$ \\
$\begin{array}{l}\text { - Large traditional education } \\
\text { companies as well as online } \\
\text { providers have partnered } \\
\text { with likes of CCTV.com to } \\
\text { broadcast live courses to } \\
\text { students across China. }\end{array}$ & $\begin{array}{l}\text { Education providers are } \\
\text { Utilizing tools such as } \\
\text { WeChat to engage with } \\
\text { parents and students. For } \\
\text { example, they are amanging } \\
\text { dalily activities for students } \\
\text { via WeChat groups. }\end{array}$ \\
& $\begin{array}{l}\text { Offline institutions are also } \\
\text { using WeChat to deliver } \\
\text { educational content by } \\
\text { utilizing WeChat } \\
\text { Classroom. }\end{array}$
\end{tabular}


Figure 8
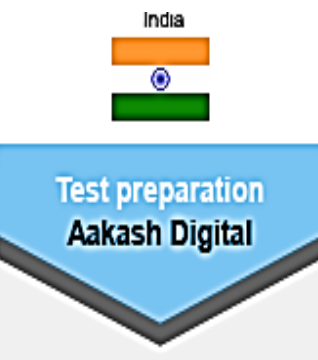

- Aakash Digital is the e-learning platform of a large brick-andmortar test prep provider in India that prepares students for medical and engineering entrance exams.

- In the midst of the COVID-19 pandemic, it is offering free access to recorded video lectures through Aakash iTutor, for all NEETIJEE 2020 aspirant and MeritNation Live classes for Classes VI to XII to cover the school syllabus until April 30 .

The Switching of Core Education
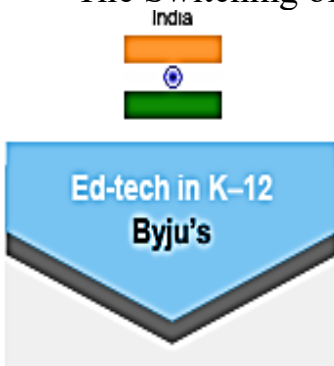

- Byju's is an online tutoring firm based in India that provides educational content focused on the $\mathrm{K}-12$ segment.

- When schools in India closed during the COVID-19 crisis, Byju's announced that it would provide free access to its complete app to schoo students until the end of April.

- Within seven days of making its app free, Byju's saw a $60 \%$ increase in the number of new users, up from $2.8 \mathrm{~m}$ paid users in December 2019.
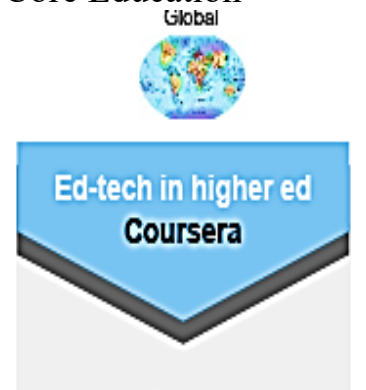

- Coursera offers massive open online courses, specializations and degrees.

- They announced free access to Coursera for Campus for any college or university impacted by COVID-19.

- This includes access to $\sim 4 \mathrm{k}$ courses across 400

specializations and up to $5 \mathrm{k}$ licenses for enrolled students at each $\mathrm{HEI}$.

- Institutions can enroll students in courses through July 2020 and students can complete them by September 2020.
Singapore (6)

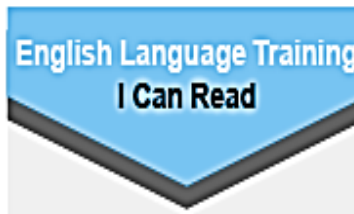

- I Can Read (ICR) Asia is a Singapore-headquartered English language training and literacy education provider that owns and operates over 150 centers across Asia and the Middle East.

- When all center-based enrichment classes were suspended across Singapore in March 2020, ICR switched to live lessons conducted via its Web-Class platform.

- Students join a live virtual classroom where teachers create interactive blackboards and interact with students through songs, builtin games and videos.

Figure 9:

The Engagement of Government Policies

\section{Select examples of measures taken by government/regulators}

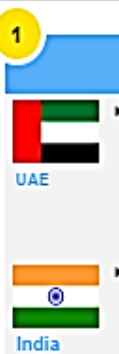

Policy measures

The Knowledge and Human

Development Authority is providing educational institutions with letters support to ask for flexibility from andlords, banks or other organizations.

ments have asked private schools to either not collect fees or offer a ciscount to parents. Other state governments have decided to not intervene in this matter.

- The Singapore MOE has asked parents and K-12 operators to micably resolve the issue of fees between themselves. In preschools. parents will get $50 \%$ off their one month school fee if their child is not attending classes during the circuit breaker period.

As per regulations, schools cannot collect fees during time off, however. the Ministry of Education and Training has allowed schools to collect fees for distance education based on expenses incurred. workload and services offered.

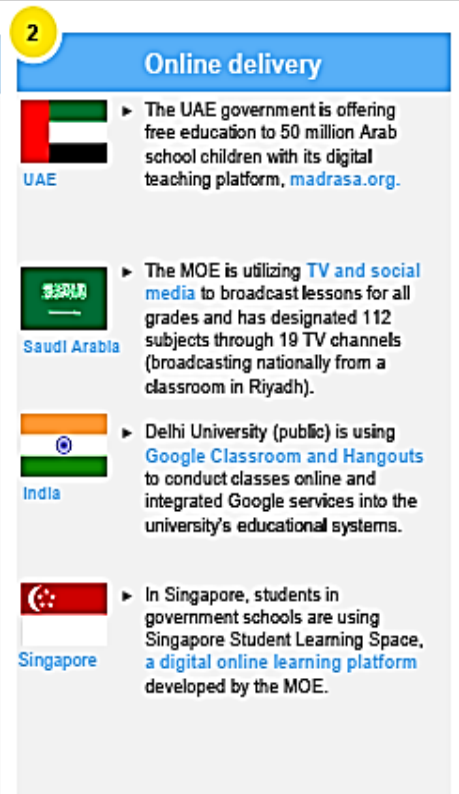


Figure 10:

The Keys Consideration of Government
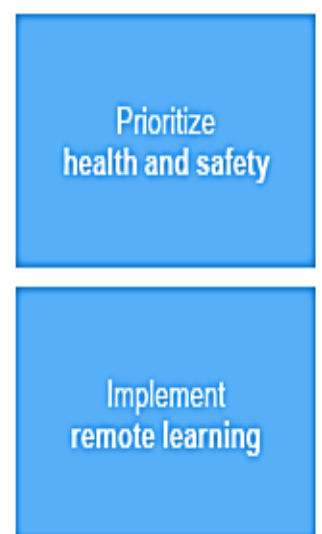

Develop

policy interventions

Create

technology

road map

- Develop comprehensive social distancing guidelines (particularly in sensitive areas such as preschools/schools)

- Define a clear post-lockdown exit strategy, with phase-wise reopening of public places, including educational institutions

- Create multiple, easy-to-access channels for supporting the public, including medical help lines addressing both physical (e.g., symptom tracker, travel history) and mental health (e.g., counseling)

- Implement remote learning for all educational institutions rapidly to minimize learning disruptions, with clear guidelines and adequate support, such as provisions for teacher training, streamlining system requirements and 50 on

- Evaluate partnerships to deliver digital learning in public schools

- Create channels to receive regular feedback from learners and parents on their experience with remote learning, and actively incorporate such feedback, where possible

- Create balanced guidelines around fee growth in the future and provide support to households, especially those that cannot afford education for their children due to the economic impact

- Offer fiscal support to private education providers to handle cash flow crunches

- Provide support in delivery of remote learning, particularly for low-fee educational institutions

- Create provisions/guidelines to factor in delays in examination and admission cycles, and potential learning gaps caused by the pandemic

- Assess current maturity of use of technology in learning (both front-end and back-end solutions)

- Define end state around online learning, e.g., extent of integration, types of solutions

- Develop continuity plans to embed online learning in educational institutions, even after the pandemic ends

- Detail key enablers and action steps to achieve end state in online learning, to be rolled out across the public and private sector

Figure 11:

The Keys Consideration of Education Providers

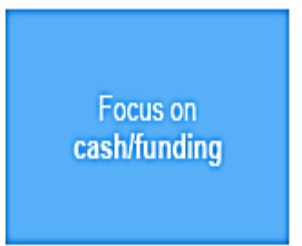

- Accelerate fee collection for term 2 and term 3 and re-registration for academic year 2021

- Roll outsscale up remote leaming capabilities by investing in online/blended learning provision

- Maintain short-term momentum (April to June) in student acquisition (e.g., digital school visits)

- Review discretionary spends (current and planned) as well as vendor contracts to boost liquidity

- Create a weekly cadence around cash management and monitoring cash flows

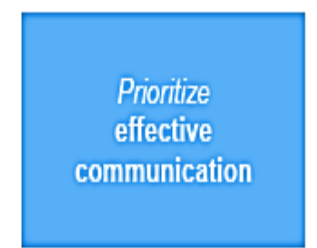

- Assemble a dedicated liais on task force, focused on active communication with key stakeholders (including students/parents, employees, regulators, vendors)

- Develop support systems for stakeholders (e.g., counseling support for students, support on working from home for staff, resources for maintaining health and wellness)

- Expand network bandwidth to handle increased digital requests

- Create targeted and empathetic marketing campaigns for existing and potential customers

Create

technology

road map

Develop a

business continuity

plan

- Assess current maturity of use of technology in learning (both front-end and back-end solutions)

- Define end state around online learning, in terms of extent of integration, types of solutions, etc.

- Develop continuity plans to embed online learning in educational institutions, even after the pandemic ends

- Detail key enablers and action steps to achieve end state in online learning (both medium and long term)

- Stress test revenue and cost assumptions in future estimates and make clear choices between cash flow and margin

- Review capital expenditure and find ways to convert it into operating expenditure (e.g., sale and leaseback), to build modularity in investment decisions

- Estimate what it will take to resume business as usual - addressing learning gaps, expat teacher hiring and retention policies, stricter health and safety policies, and other factors 
Figure 12:

The Keys Question of Educational Sector to Problem Solving

\section{Key questions $\quad$ Our preliminary hypotheses}

- We anticipate a long-term effect on private school enrolments, as well as increased fee sensitivity.

Will the education sector - The length and structural implications of the decline/slow growth would be determined by

go back to the pre-

governments' economic revitalization efforts and the support provided to parents and operators.

COVID-19 status quo

when the pandemic is

- Moreover, education providers will need to make an extra effort to showcase to parents their

brought under control? health and safety credentials.

Will online learning

- Traditional (offline) leaming was already being counterbalanced by online/blended modes to a smaller extent.

across $\mathrm{K}-12$ and higher education become the new normal?

- We will continue to see a growth in online education across the board, even after the pandemic subsides.

- However, the in-person aspect of the learning experience will continue to play an important part physical campuses will not be replaced by online learning.

- Providers that do the following will find success:

- Adapt nimbly to the changing landscape

- Embed digital leaming solutions into their systems

- Retain loyalty of core target audience to bounce back

Who will win, and who

will lose?

- Broadly, ed-tech providers (both business to business and business to consumer) are expected to see an uptick in the medium and long term.

- Brick-and-mortar education businesses that do not have the agility or resources to respond actively to the evolving landscape will struggle.

\section{Figure 13:}

The Rising Cases of Southeast Asia on Educational System Transformation mid and forth Pandemic

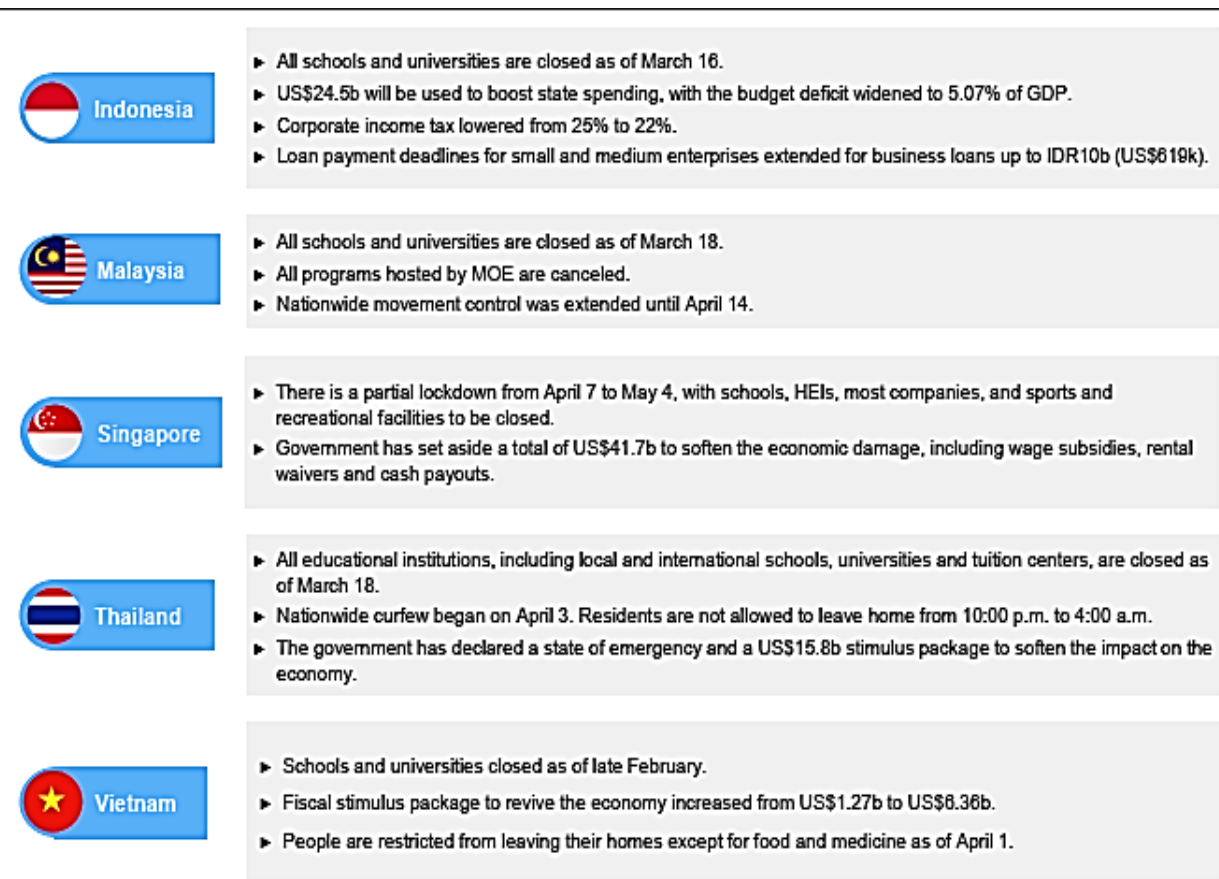


Figure 14:

The Widespread Effect of Corona Virus

\section{Impact on economy}

- Drop in crude prices will impact commodity-sensitive countries such as Algeria, Angola, Ghana and Nigeria.

- There has been a drop in tourism, which contributes more than $10 \%$ of GDP in countries such as Seychelles and Cape Verde.

- Pullback from African markets, as well as a projected decline in export revenue, has led to depreciation of local currencies.

- Due to lower and uncertain demand, business confidence will decrease and cause declines in investment. The expected reduction in the region is $1 \%-3 \%$.

\section{Impact on learners}

- Total impact on $200 \mathrm{~m}+$ learners across preschool, K-12 and tertiary education

- All schools and universities are shut down until further notice.

- Private schools can expect a decline in enrolment due to low inflow of expatriates across the year into countries such as South Africa and Nigeria.

- A few countries, such as South Africa and Zambia, have a high proportion of distance learning students $(>30 \%)$. Countries with lower proportion of distance learning students might find it harder to switch to distance/online learning.

- There is increased risk of university dropouts due to the expected recession. With no recession, countries in the region have a high dropout rate (>40\%).

\section{Government plans}

While only a small proportion of Africa's population has access to mobile/e-learning, governments are using alternate media to enable continuous delivery of education:

- Broadcast radio: $80 \%-90 \%$ of households have access to radio

- Television: 75 million in the region have access to TV.

Figure 15:

The Hollow cost of System Shut Down by the Corona Virus

\section{Preschool and $\mathrm{K}-12$}

- For preschools, since session ends in March and reopens in June, the COVID-19 pandemic has not had much impact.

- The Central Board of Secondary Education (CBSE) has announced that all students from grades 1 to 8, will be promoted to higher classes without examinations.

- For grades 8 to 12 , schools have been advised to promote students, though this has not been mandated. CBSE has not yet made a decision on board examinations for grades 10 and 12. Examinations shall only be conducted for major subjects, and CBSE also will give a 10-day notice before rescheduling the examinations.

- Private schools such as GIIS vill offer virtual classrooms through their proprietary EduERP system developed by GIIS R\&D.

\section{Higher education}

- Universities in India have suspended campus gatherings until further notice. Private institutions such as Shiv Nadar and Ashoka University, as well as public institutions such as Delhi University, are switching to an online medium using Zoom and Blackboard.

- Coursera has also made its courses free for universities to use.

\section{Ed-tech}

- A clutch of ed-tech providers such as UpGrad, Vedantu, Imarticus, Simplileam and Toppr have seen an increase in demand.

- Simplilearn saw a 15\% increase in sales in March; inquiries at UpGrad have increased by $50 \%$, whereas K-12 platform Toppr has seen a $100 \%$ month-on-month increase.

- Ed-tech plattorms are also using partnerships to increase growth. For example, UpGrad has partnered with Agora.jo to offer UpGrad courses to all colleges and universities in India for free. 
Figure 16:

The Waves of Lock Down

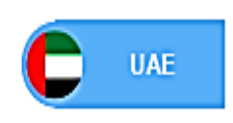

- Schools and universities to provide distance learning to students until the end of 2020 year

- USS34b combined economic package announced by central government and central bank to revive the economy

- Automatic renewal of work permits and visas, and exemption from medical tests for workers

- All educational institutions expected to be closed until further notice

- Finance Ministry pledge of US\$20b to support economic growth

- Central bank launch of u USS20b stimulus package to buoy economy

The proliferation of the coronavirus (also named COVID-19, the novel coronavirus, new coronavirus or corona pandemic) has created a global, regional, national, political, societal, economic and commercial crisis (Karabag, 2020). The spread of COVID-19 and the response of governments, individuals, and businesses will have major effects on the health of individuals, the health of the economy, and the finances of the government. In addition, fear and uncertainty will lead to difficult-to-predict responses, including panic selling in the stock market and further cutbacks in consumption to conserve resources for hard times ahead, (Marren \& Acquiro, 2020). The restrictions on mobility created by social distance have diminished economic supply and demand, severely impacting businesses and jobs.

In other risk situation another countries are at different points in their (COVID-19) infection rates, worldwide there are currently more than (1.2) billion children in (186) countries affected by school closures due to the pandemic. Alibaba's distance learning solution, DingTalk, had to prepare for a similar influx: "To support large-scale remote work, the platform tapped Alibaba Cloud to deploy more than $(100,000)$ new cloud servers in just two hours last month - setting a new record for rapid capacity expansion", Li \& Lalani (as cited in DingTalk CEO; 2020). For those who do have access to the right technology, there is evidence that learning online can be more effective in a number of ways. To get the full benefit of online learning, there needs to be a concerted effort to provide this structure and go beyond replicating a physical class/lecture through video capabilities, instead, using a range of collaboration tools and engagement methods that promote "inclusion, personalization and intelligence". 
Figure 17:

Covid 19 Affected the Stage of Global Education

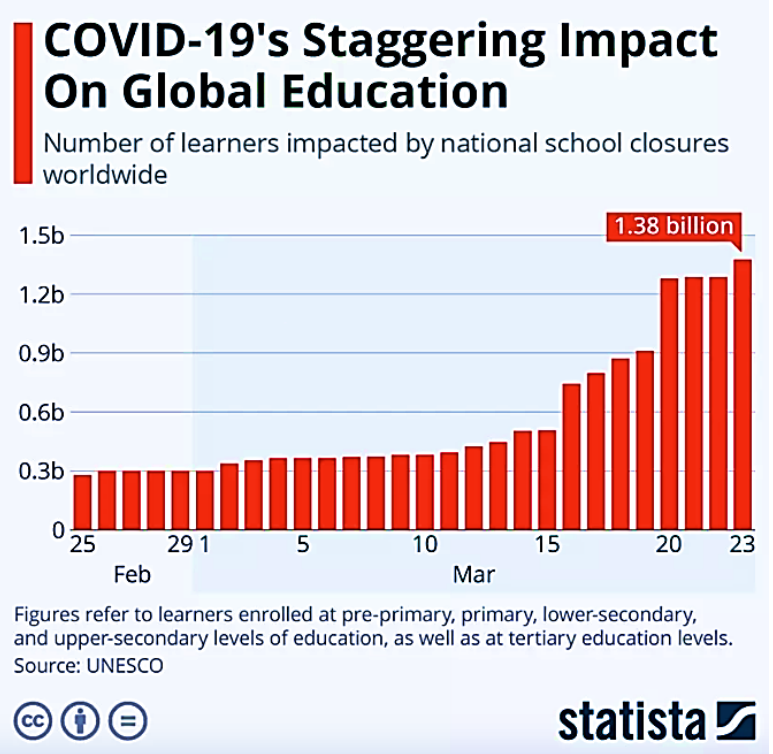

The economic crisis is a phase of economic cycle in which a relative surplus of goods is formed in relation to the limited purchasing capacity of the population, leading to decreased production, bankruptcies, unemployment (Haralambie, 2011). There is a variety of crisis theory and crisis intervention models used to explain how crises develop and what it means for an individual to need crisis intervention (MacDonald, 2016). The lists several crisis definitions, which are an important precursor to understanding crisis theory, such as: people are in a state of crisis when they face an obstacle to important life goals-an obstacle that is, for a time, insurmountable by the use of customary methods of problem-solving. Crisis Formation A negative event occurs which leading to a feeling of subjective distress this distress leads to impairment in functioning coping skills fail to improve the functioning The term "cognitive key" refers to your belief about the negative event, which influences how well you will be able to cope with the event.

In addition, (MacDonald, 2016b) Modern Applied Crisis Theory While Caplan and Lindemann's work has been influential and is important in understanding the development of crisis intervention it is insufficient for describing modern mental health crises that may develop without a single precipitating event or pre-existing mental health issues. Existential Crisis Existential crises are based on larger concepts of a person's purpose and attainment of actualization, a deep sense of personal fulfilment. Often existential crises are related to situations of regret or belief that life has passed them or realization that one will not reach goals they had set for themselves at a certain age.

In crisis knowledge it is grounded on seven theories which are psychoanalytic theory, systems theory, ecosystems theory, adaptational theory, interpersonal theory, chaos theory, and developmental theory-other relevant framework that applied based on crisis theory constructed in term of model of crisis intervention which covered equilibrium model, cognitive model, psychosocial transition model, developmental ecological model, and contextualecological model (MacDonald, 2016c). 


\section{English Language Circles and Language Death}

The term World Englishes, not World English, refers to emerging localized or indigenized varieties of English, especially the varieties which have developed in territories influenced by the United Kingdom (Great Britain) or the United States. The English language in this circle represents the traditional historical and sociolinguistic bases in the regions where it is now used as English as the Native Language (ENL): the United Kingdom, the United States, Australia, New Zealand, Ireland, Canada, South Africa, and some of the Caribbean territories. The Outer Circle of English was made during the second diaspora of English, which diffused the language through the expansion of Great Britain. The total number of English speakers is estimated to range from (150) million to (300) million (Lee \& Jun, 2016).

Figure 18:

The Circles of English Language

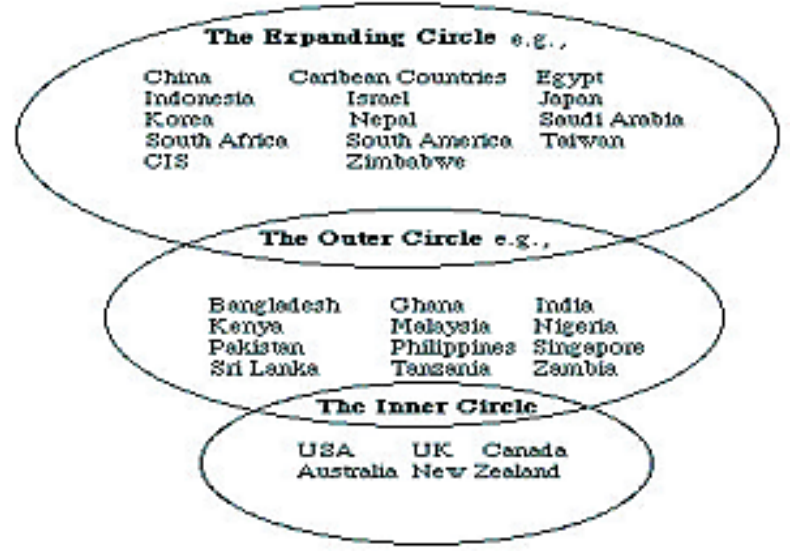

In generous the "inner" circle pride of place stresses the position of the "native speaker" and the mystique that surrounds the native as being an authority on her language speaking a supposedly "pure" form linked with genes or blood and place of birth (Schmitz, 2014). In language development, a language can be defined as ultimately, "rules" for combining words cannot be rules about particular words but must be rules about classes of words such as nouns, verbs or prepositions. Once these abstract blueprints are available, the speaker can fill the "slots" in a sentence with the words that best convey the message of the moment (Johnston, 2010). In line, the debatable issue which endures to scaffold such as one group of theorists argues that language input merely triggers grammatical knowledge that is already genetically available. The opposition argues that grammatical knowledge results from the way the human mind analyzes and organizes information and is not innate. This debate reflects fundamentally different beliefs about human development and is not likely to be resolved.

Language endangerment may be the result of external forces such as military, economic, religious, cultural, or educational subjugation, or it may be caused by internal forces, such as a community's negative attitude towards its own language. Above all, speakers of these languages may experience the loss of their language as a loss of their original ethnic and cultural identity (Johnson \& Elder, 2002). Raising awareness about language loss and language diversity will only be successful when meaningful contemporary roles for minority languages can be established, for the requirements of modern life within the community as well as in national and international contexts. In this regard, he remarks, the professional discourse around English language teaching disconnects culture from the structure by delimiting the focus in language pedagogy to technical matters that is language and education in a narrow sense, to the exclusion of social, economic and political matters. Global business practices help market 
(ELT). The huge multinational companies like Microsoft and Coca Cola which are mostly owned by Centre nations, write the instructions accompanying their products in English (Chowdhury, 2013).

How and why do dialects die? Languages can vanish exceptionally quickly on the off chance that all or most of their speakers kick the bucket as a result of natural disasters, war or genocide. Irresistible maladies to which innate people groups have no resistance can moreover have a divesting impact on those individuals and their dialects. Numerous individuals, particularly those from transcendently monolingual nations, accept that the world would be distant better; a much better; a higher; a stronger; an improved [a stronger put full of shared understanding and peace] in the event that everybody talked the same dialect. The financial taken a toll of interpreting and translating between languages is progressed as another contention in support of a monolingual world. Dialects can moreover have a positive economic impact on tourism, offer assistance to bring and keep communities together and deliver them selfassurance and a sense of pride in their culture and personality (Ager, 2009).

\section{The English Foreign Language Practice in the Mid of Pandemic}

In general issue that encountered by Tiongkok land during the pandemic can be seen such as the number of confirmed cases and deaths continues to climb upwards globally even when it starts to climb downwards within China [National Health Commission of the People's Republic of China 2020], leaving China now fighting to contain imported cases from overseas passengers alongside their own struggles to recover from a national shutdown (Peters et al., 2020). Global Understudy Issues kept in contact with adoration and backing to global understudies, underscored and reproved the need to remain inside, keep away from groups and get-togethers; Some universal understudies (particularly the individuals who are in their nations of origin) face arrange issues, and time contrast is a test. We are supplicating that this emergency will reach a conclusion soon.

In similar to United State case when pandemic preoccupied The [US] instruction framework was not built to deal with expanded shutdowns like those forced by the [COVID-19] widespread. Instructors, administrators, and guardians have worked difficult to keep learning alive; by the by, these efforts are not likely to provide the quality of instruction that's conveyed in the classroom. Even more upsetting is the setting: the persistent achievement incongruities over wage levels and between white understudies and understudies of dark and Hispanic legacy. School shutdowns might not only cause unbalanced learning misfortunes for these students - compounding existing gaps - but also lead more of them to drop out. This may have long-term impacts on these children's long-term economic well-being and on the US economy as an entirety (Dorn et al., 2020).

The average a black or Hispanic student remains roughly two years behind the average white one and low-income students continue to be underrepresented among top performers. We estimate that if the black and Hispanic studentachievement gap had been closed in [2009], today's [US GDP] would have been [\$426 billion to $\$ 705]$ billion higher. If the income achievement gap had been closed, we estimate that [US GDP would have been $\$ 332$ billion to $\$ 550$ ] billion higher. These estimates were made before schools closed and the transition to remote learning began, sometimes chaotically (Dorn et al., 2020b). 
Figure 19:

Learning loss and school closures

Lost economic potential in

2019 resulting from gap, $\$$ billion $\%$ of total 2019 GDP

\begin{tabular}{|c|c|c|}
\hline $\begin{array}{l}\text { GDP gap: Black and } \\
\text { Hispanic students } \\
\text { Estimated GDP gains if black and } \\
\text { Hispanic students performed at } \\
\text { the same level as white students' }\end{array}$ & 426-705 & $\begin{array}{l}2.0-3.3 \\
\text { of GDP }\end{array}$ \\
\hline $\begin{array}{l}\text { GDP gap: Income } \\
\text { Estimated GDP gains if low-income } \\
\text { students performed at the same } \\
\text { level as high-incorne students }{ }^{2}\end{array}$ & 332-550 & $\frac{2.0-2.6}{\text { of GDP }}$ \\
\hline $\begin{array}{l}\text { Earnings gap } \\
\text { Estimated additional earnings if } \\
\text { black and Hispanic students } \\
\text { performed at the same level as } \\
\text { white students' }\end{array}$ & 238-318 & $\begin{array}{l}7.8-10.5 \\
\text { of earnings }\end{array}$ \\
\hline
\end{tabular}

Dorn et al (2020c) confirmed that we likewise displayed three epidemiological situations. In the main-"infection contained"- in-class guidance resumes in fall [2020]. In the second-"infection resurgence"- school terminations and low maintenance plans proceed irregularly through the 2020-21 school year, and in-school guidance doesn't completely continue before January [2021]. In the third situation - "pandemic acceleration" - the infection isn't controlled until immunizations are accessible, and schools work distantly for the whole [2020-2021] school year. In practice to the detail of that phases above, can be described such as In our subsequent situation [in-class guidance does not continue until January 2021], we gauge that understudies who remain selected could lose three to four months of learning on the off chance that they get normal far off guidance, seven to 11 months with lower quality far off guidance, and [12 to 14] months if they don't get any guidance whatsoever.

The other perspective of the impact to education is found on Indonesia scope which from the data processing results and the analysis shows the average of the data obtained from the two campuses above, about of students from tertiary institutions who are the object of research are ready to adapt with online lectures even though there are those who find it difficult to use the application used as much as are ready to adapt. The result of student's loss or dropout and anything worse if that is permitted to continue on would have disastrous implications for students' mental health. This study shows how much they favor (Watnaya et al., 2020):

i. About [60.5\%] of students from tertiary institutions who are the object of research are ready to adapt with online lectures even though there are those who find it difficult to use the application used as much as $[32.5 \%$ but around $47.5 \%]$ are ready to adapt. Most activities in COVID-19 states follow internet talks conducted by speakers. In fact, the psychological strain generated for the students from the surveyed data indicates that the students who have trouble sleeping because of the effects of this challenge are about $60 \%$, the average figure for the two campuses;

ii. Surprisingly, [92\%] of the students prefer face-to - face lectures in classrooms over online lectures. This study shows how much they favor. In all universities in Indonesia and the world, this research is used to find the best terminology on the online lecture scheme, to provide review, to debate and to respond to policies taken and to turn them into an comprehensive education system work project, which will future be looked at by various organizations.

English medium teaching in such countries is often designed to attract students from elsewhere; a substantial proportion of those being taught in English 
may comprise non-mobile local students such as Chinese and Japanese students studying academic subjects in English medium in, respectively, Chinese and Japanese universities. For although we tend to think of the two as going hand in hand, and language travelling with people, where higher education is concerned it is increasingly the case that the language, English, 'travels' while many people remain in situ either in locally run English medium instruction (henceforth EMI) universities or in 'branches' (also known as 'offshore campuses') of other, predominantly Anglophone-led, institutions (Canagarajah, 2020, p. 2).

Meanwhile, internationalization with respect to universities, they note, tends to mean "the integration of an international or intercultural dimension into the tripartite mission of teaching, research and service functions of Higher Education" (Canagarajah, 2020, p. 2b). The most obvious way in which universities has been adding an international dimension to their profile has been by recruiting students - and to a lesser extent, staff - from other countries. The goal is not internationalization per se, but that English medium instruction has been introduced primarily "to attract fee-paying international students" as well as "to enhance the university's international prestige and contacts" and "develop the English language skills of their staff and students".

In the other side of English foreign language teachers have carried out online learning through a series of activities ranging from checking the students' attendance to giving a score on the students' works synchronously or asynchronously depending on each school policy due to the [COVID-19] pandemic. Planning and preparation should inevitably be done for better online learning in the future since online learning requires more time than a face-to-face class to be well-prepared and ready (Atmojo \& Nugroho, 2020).

\section{Conclusion and Recommendation}

According to the various researcher that postulated their findings to the impact of corona virus in all aspect, which included of educational sectors and also narrowed to English language teaching and learning. Researcher concluded that by this time corona virus have been influencing all of the aspect of human beings and widespread from the top-down as a verse. Therefore, to the third circle of English as a foreign language in crisis time such a global virus impact is the threat to loss even language can be dead because of the situation, policymaker, socio-culture, economic degradation which strike to influence such a snowball.

In other side, researcher was found the difficulties in enlarge the discussion of English language teaching and learning issue. Mostly of the research papers were discussed of the general impact to the global sectors and likewise in education field. So that in the future, others researcher can be scaffold in radical of English language teaching and learning issue to the pandemic affect. Moreover when other researcher will able to discuss in radical, one hand can be able to all of the [ELT and EFL] stakeholder and also practitioner to improve their capacity to manage the teaching and also education system in mid of various crisis, because of they have opportunity to adopt and adapt any kinds of scientific information to the purpose of sustainable development.

\section{Reference}

Ager, S. (2009). A Study of Language Death and Revival with a Particular Focus on Manx Gaelic. An assessment of the current state of the Manx Gaelic language. https://omniglot.com/pdfs/languagerevival.pdf. 
Atmojo, A. E. P., \& Nugroho, A. (2020). EFL Classes Must Go Online! Teaching Activities and Challenges during COVID-19 Pandemic in Indonesia. Register Journal, 13(1), 49-76. https://doi.org/10.18326/rgt.v13i1.49-76

Canagarajah, S. (Ed.). (2020). Mobility and English Language Policies and Practices in Higher Education. In The Routledge Handbook of Migration and Language Edition: 1st (1st ed., Vol. 1st, pp. 1-18). Routledge.

Chowdhury, M. K. B. (2013, May). Is the Spread of English as a World Language a Positive or a Negative Development? 11249 Oregon Circle Bloomington, $\quad$ MN 55438 USA. http://www.languageinindia.com/may2013/chowdhuryenglish1.pdf.

Dorn, E., Hancock, B., Sarakatsannis, J., \& Viruleg, E. (2020). (working paper). COVID-19 and student learning in the United States: The hurt could last a lifetime (Ser. Public Sector Practice, pp. 1-9). New York, United State: CUNY. Retrieved from mckinsey.com/industries/public-and-socialsector/our-insights/covid-19-and-student-learning-in-the-united-states-thehurt-could-last-a-lifetime

English in Language Policy and Management. (2012). In The Cambridge Handbook of Language Policy.: Vol. B.(ed) 2012 (pp. 1-33). Cambridge University

Press. https://www.researchgate.net/publication/236606713 English_in_Languag e Policy and Management'

Haralambie, G. (2011). The Global Crisis and Cyclical Theory. Örebro. http://store.ectap.ro/articole/664.pdf.

Jhingan, A., Sarathy, A., Gajendra, R., Cernuta, B., Kathuria, A., \& Krishnamurthy, S. (2020). (rep.). Covid-19 Assessing the Impact on the Education Sector and Looking Ahead (Ser. Agenda Impact of Covid-19, pp. 1-21). Blenheim House, Fountainhall Road, Aberdeen AB15 4DT, United Kingdom: EY Parthenon.

Johnston, J. (2010, January). Factors that Influence Language Development. Language Development and Literacy 2nd edition. http://www.childencyclopedia.com/sites/default/files/textes-experts/en/622/factors-thatinfluence-language-development.pdf.

Karabag, S. F. (2020). An Unprecedented Global Crisis! The Global, Regional, National, Political, Economic and Commercial Impact of the Coronavirus Pandemic. Canda. http://www.aebrjournal.org/about-jaebr.html.

Li, C., \& Lalani, F. (2020, April 29). The COVID-19 Pandemic has Changed Education Forever. This is How. https://www.weforum.org/agenda/2020/04/coronavirus-education-globalcovid19-online-digital-learning/.

Lee, Y. hun, \& Jun, K. suk. (2016). The Inner Circle vs. the Outer Circle or British English vs. American English. Soul.

Marren, H. J. F., \& Acquiro, S. J. (2020). (rep.). Coronavirus Economic Impact: County Sales Tax Revenue Projections (Ser. March, pp. 1-10). New York, America: NYSAC.

MacDonald, D. K. (2016, June 13). [web log]. http://dustinkmacdonald.com/crisis-theory-types-crisis/.

Peters, M. A., Wang, H., Ogunniran, M. O., Huang, Y., Green, B., Chunga, J. O., Hayes, S. (2020). China's Internationalized Higher Education During Covid-19: Collective Student Autoethnography. Postdigital Science and Education, 1-21. https://doi.org/10.1007/s42438-020-00128-1

Schmitz, J. R. (2014). Looking under Kachru's $(1982,1985)$ three circles model of World Englishes: the hidden reality and current challenges. Revista Brasileira De Linguística Aplicada, 14(2), 373-411. https://doi.org/10.1590/s1984-63982014005000010 
Watnaya, A. K., Muiz, M. H., Sumarni, N., Mansyur, A. S., \& Zaqiah, Q. Y. (2020). Pengaruh Teknologi Pembelajaran Kuliah Online Di Era Covid-19 Dan Dampaknya Terhadap Mental Mahasiswa. EduTeach : Jurnal Edukasi Dan Teknologi Pembelajaran, 1(2), 153-165. https://doi.org/10.37859/eduteach.v1i2.1987 